UDC 622.24(07)

\title{
The application of calcium polysulfide to increase corrosion resistance of the timbering of wells
}

\author{
Authors: \\ Farit A. Agzamov, \\ Professor, Ufa State Petroleum Technological University, Ufa, Bashkortostan Republic, Russia, \\ faritag@yandex.ru; \\ Elvira F. Tokunova, \\ PhD of Chemistry, Associate Professor, Ufa State Petroleum Technological University, Ufa, Bashkortostan Republic, Russia, \\ etokunova@yandex.ru;
}

\section{Rival R. Sabirzianov,}

Graduate Student, Ufa State Petroleum Technological University, Ufa, Bashkortostan Republic, Russia, rivalsaab@gmail.com

Abstract: The cement slurries used in well casing should ensure the tightness of the lining and protect the casing from aggressive formation fluids. At the same time, cement and water based solutions are used for cementing, with a water-cement ratio of $0.45-0.9$, which predetermines their high porosity and low corrosion resistance.

The technologies for increasing the durability of concrete used in con-struction practice when fixing wells are not acceptable.

One of the most aggressive components of reservoir fluids is hydrogen sulfide, depending on thermodynamic conditions, can be both dissolved and gaseous.

The analysis of various types of corrosion of cement stone shows the ki-netics is determined by the diffusion of aggressive ions into the stone.

To reduce the porosity of the cement stone, calcium polysulfide has been proposed, which can precipitate in the pores of the stone during hardening of the cement slurries, clogging the pores, reducing their size, slowing down the diffusion rate of aggressive ions into the cement stone. In addition, calcium polysulfide adsorbing in the pores on cement hardening products will ensure the inhibition of pore space.

Three methods of calcium polysulfide injection into the cement slurries were tested: into the tempering fluid (water), directly into the prepared cement slurry and dry method, through cement powder, which was subsequently subjected to disintegrator treatment.

The results of the experiments showed calcium polysulfide make an impact on the rheological properties and pumpability of cement slurries, increasing the strength of the obtained stone and reducing its permeability.

The stability of a stone in an acidic environment was estimated by its corrosion by one molar hydrochloric acid. The depth of stone corrosion with increasing concentration of PSS decreased from 30 to $6 \mathrm{~mm}$ in 21 days.

When testing the cement stone under the action of dissolved hydrogen sulfide for 45 days, it was shown that the increased concentration of calcium polysulfide from 0 to $5 \%$ reduced the corrosion depth from 5.0 to $0.3 \mathrm{~mm}$, depending on the technology of adding the reagent.

Micrographs of cement stone samples proved that calcium polysulfide, being distributed in the pore space, blocks the surface of the cement stone, limiting the contact of aggressive ions with hardening products.

Keywords: Cement stone, hydrogen sulfide, increase in corrosion resistance, calcium poly-sulfide.

For citation: Agzamov F.A., Tokunova E.F., Sabirzianov R.R. The application of calcium polysulfide to increase corrosion resistance of the timbering of wells. Nanotehnologii v stroitel'stve = Nanotechnologies in Construction. 2019, Vol. 11, no. 3, pp. 308-324. DOI: 10.15828/2075-8545-2019-11-3-308-324. 

property="cc:attributionName" rel="cc:attributionURL" $>$ Agzamov F.A., Tokunova E.F., Sabirzianov R.R. $</ a>$ is licensed under a $<$ a rel="license" href="http://creativecommons.org/licenses/by/4.0/" >Creative Commons Attribution 4.0 International License $</ \mathrm{a}>.<\mathrm{br} />$ Based on a work at $<\mathrm{a}$ xmlns:dct="http://purl.org/dc/terms/" href="http://nanobuild.ru/en_EN/nanobuild-3-2019/" rel="dct:source" $>$ http://nanobuild.ru/en_EN/nanobuild-3-2019/</a $>.<$ br $/>$ Permissions beyond the scope of this license may be available at $<$ a xmlns:cc="http://creativecommons.org/ns\#" href="faritag@yandex.ru" rel="cc:morePermissions" $>$ faritag@yandex.ru</a $>$.

\title{
Применение полисульфида кальция для повышения коррозионной стойкости крепи скважин
}

\author{
Авторы: \\ Агзамов Фарит Акрамович, \\ ФГБОУ ВО «УГНТУ», г. Уфа, Россия, профессор, faritag@yandex.ru; \\ Токунова Эльвира Фаритовна, \\ ФГБОУ ВО «УГНТУ», г. Уфа, Россия, доцент кафедры, etokunova@yandex.ru; \\ Сабирзянов Риваль Рамилевич, \\ ФГБОУ ВО «УГНТУ», г. Уфа, Россия, магистрант кафедры, rivalsaab@gmail.com
}

Резюме: Цементные растворы, применяемые при креплении скважин, должны обеспечить герметичность крепи и защитить обсадную колонну от агрессивных пластовых флюидов. При этом для цементирования используются растворы на основе цемента и воды, при водоцементном отношении 0,45-0,9, что предопределяет их высокую пористость и низкую коррозионную стойкость.

Технологии повышения долговечности бетонов, применяемые в строительной практике, при креплении скважин не приемлемы.

Одним из наиболее агрессивных компонентов пластовых флюидов является сероводород, который в зависимости от термодинамических условий может находиться как в растворенном, так и газообразном состоянии.

Анализ различных видов коррозии цементного камня показывает, что кинетика многих из них определяется диффузией агрессивных ионов внутрь камня.

Для снижения пористости цементного камня предложено применение полисульфида кальция, который может осаждаться в порах камня при твердении цементного раствора, кольматируя поры, уменьшая их размер, замедляя скорости диффузии агрессивных ионов внутрь цементного камня. Кроме того, полисульфид кальция, адсорбируясь в порах на продуктах твердения цемента, будет обеспечивать ингибирование порового пространства.

Было опробовано три способа введения полисульфида кальция в цементный раствор: в жидкость затворения (воду), непосредственно в приготовленный цементный раствор и сухой способ, через порошок цемента, подвергаемый впоследствии дезинтеграторной обработке.

Результаты экспериментов показали, что полисульфид кальция не оказывает влияния на реологические свойства и прокачиваемость тампонажных растворов, повышая прочность полученного камня и снижая его проницаемость.

Стойкость камня в кислой среде оценивалась по его коррозии одномолярной соляной кислоте. Глубина коррозии камня с повышением концентрации ПСС снизилась от 30 до 6 мм за 21 сутки.

При испытании цементного камня под действием растворенного сероводорода в течение 45 суток было показано, что увеличение концентрации полисульфида кальция от 0 до 5\% снизило глубину коррозии от 5,0 до 0,3 мм, в зависимости от технологии ввода добавки.

Микрофотографии образцов цементного камня подтвердили, что полисульфид кальция, распределяясь в поровом пространстве, блокирует их поверхность, ограничивая контакт агрессивных ионов с продуктами твердения. 
CONCRETE AND MORTARS MODIFIED BY NANOSIZE ADDITIVES • БETOНЫ И РАСТВОРЫ, МОДИФИЦИРОВАННЫЕ НАНОРАЗМЕРНЫМИ ДОБАВКАМИ

Ключевые слова: цементный камень, сероводород, повышение коррозионной стойкости, полисульфид кальция.

Для цитирования: Агзамов Ф.А., Токунова Э.Ф., Сабирзянов Р.Р. Применение полисульфида кальция для повышения коррозионной стойкости крепи скважин // Нанотехнологии в строительстве. - 2019. - Том 11, № 3. - C. 308-324. - DOI: 10.15828/2075-8545-2019-11-3-308-324.

\footnotetext{
Machine-readable information on CC-licenses (HTML-code) in metadata of the paper

$<$ a rel="license" href="http://creativecommons.org/licenses/by/4.0/" ><img alt="Creative Commons License" style="border-width:0" src="https://i.creativecommons.org/l/by/4.0/88x31.png"/></a $><$ br / $><$ span xmlns:dct="http://purl.org/dc/terms/" href="http://purl.org/dc/dcmitype/Text" property="dct:title" rel="dct:type" $>$ The application of calcium polysulfide to increase corrosion resistance of the timbering of wells. $</$ span $>$ by $<$ a xmlns:cc="http://creativecommons. org/ns\#" href="Nanotehnologii v stroitel'stve = Nanotechnologies in Construction. 2019, Vol. 11, no. 3, pp. 308-324. DOI: 10.15828/2075-8545-2019-11-3-308-324." property="cc:attributionName" rel="cc:attributionURL" $>$ Agzamov F.A., Tokunova E.F., Sabirzianov R.R. $</ a>$ is licensed under a $<$ a rel="license" href="http://creativecommons.org/licenses/by/4.0/" >Creative Commons Attribution 4.0 International License $</ \mathrm{a}>.<\mathrm{br} />$ Based on a work at $<\mathrm{a}$ xmlns:dct="http://purl.org/dc/terms/" href="http://nanobuild.ru/en_EN/nanobuild-3-2019/" rel="dct:source" $>$ http://nanobuild.ru/en_EN/nanobuild-3-2019/</a $>$. $<$ br $/>$ Permissions beyond the scope of this license may be available at <a xmlns:cc="http://creativecommons.org/ns\#" href="faritag@yandex.ru" rel="cc:morePermissions" $>$ faritag@yandex.ru</a $>$.
}

Статья поступила в редакцию: 21.04.2019.

Статья поступила в редакцию после рецензирования: 15.05.2019.

Статья принята к публикации: 26.05.2019.

\section{INTRODUCTION}

A ggressive effects on cement stone exhibit, without exception, acids and numerous salts. Formation waters of many deposits contain various dissolved salts and are extremely aggressive with respect to the cement stone [1, 2].

The analysis of various types corrosion of cement stone [3-8] shows the kinetics is determined by the diffusion of aggressive ions into the stone. This refers to corrosion under the action of acidic environments, sulfate, magnesia corrosion. During leaching corrosion, the kinetics of diffusion of calcium ions from the cement stone also has diffuse control.

The dense aggregate concrete with a low water-cement ratio $(\mathrm{W} / \mathrm{C})$ or im-pregnation of products with special compositions [9-11] is known to be used to increase the durability of structures in industrial and civil construction.

In the construction of wells, these technologies are unacceptable, since cement and water-based solutions are used for cementing with $\mathrm{W} / \mathrm{C}=0.45-0.9$, sometimes containing modifying additives. Reducing the water-cement ratio of cement slurries leads to an increase in the density of the solution and can cause complications or accidents when cementing. In addition, a decrease in the $\mathrm{W} / \mathrm{C}$ solution leads to a loss of mobility, and the use of plasticizers can cause sedimentation separation of the cement solution [1, 12].

The application of impregnating materials to improve the durability of cement stone in downhole conditions is impossible, because the cement-water slurry used in cementing wells is pumped for $1-4$ hours inside the casing and in the annulus with small diameters of pipes and small (15-20 mm) annular gaps at depths a few kilometers away.

For timbering of the wells that consist of a casing and a cement sheath of small thickness, the most weak element is a cement stone that works in constant contact with aggressive formation fluids and is vulnerable to their effects.

The article presents the results of a studies of the influence of nanosized particles of calcium polysulfide on the properties of cement stone used in the timbering of oil and gas wells. As part of the research, experiments were conducted to assess the effects of calcium polysulfide on cement slurries and the resulting stone, its durability in a hydrogen sulfide environment. Electron microscopy made it possible to evaluate the role of nanosized particles of calcium polysulfide to increase the corrosion resistance of cement stone.

\section{MAIN PART}

Theoretical aspects of hydrogen sulfide corrosion the cement stone

Hydrogen sulfide, the amount of which in gas reservoir can reach up to $25 \%$ is the most aggressive component of reservoir fluids $[13,14,15]$. The mechanism of damage and the factors determining the kinetics of the process are described in detail in [1, 2, 7, 13-15]. The conditions for the destruction of the stone during gas hydrogen sulfide aggression are the high porosity of the stone, which ensures the penetration of the aggressor deep into the stone, and the high $\mathrm{pH}$ of the hardening products, ensuring the formation of slightly soluble calcium sulfide. The 
accumulation of the latter leads to the development of tension stresses in the cement stone. A secondary factor in the appearance of tension stresses may be the formation of ettringite during the transition of sulfide sulfur to sulfate. The most vulnerable to hydrogen sulfide gas is the stone from Portland cement, whereas stone samples with $\mathrm{pH} \leqslant 11$, obtained from scoriaceous binders at high temperatures, proved to be resistant [14, 16].

Under the action of dissolved hydrogen sulfide on cement stone, corrosion of the first type is observed (according to V.M. Moskvin) [3, 4, 13, 14], and sam-ples of stone from all types of binders, with the exception of acidresistant cement, are destroyed, and that concerns only rate of the process. At the same time, the defeat process is stratified inherent in acid corrosion.

The kinetics of the corrosion process is determined by the concentration of the corrosive medium at the border with the cement stone, the composition and density of the corrosion product layer, the reaction capacity of the cement stone, and can be described by various kinetic curves [17].

For cement stones in deep wells, when the rate of supply of an aggressive agent to the sample surface is greater than its diffusion in the pores of the stone, the most effective way to slow down corrosion is to control the structure of the pore space, which has become the main task of research.

Unfortunately, the technological methods widely used in construction are practically impossible to use when cementing casing strings in deep wells, although work has been done in this direction. In particular, it is possible to note the work [18], which describes the experience of using the method of chemical condensation of microdisperse particles in stone pores. A similar effect is also observed when using nanosilica additives [19].

To reduce the porosity of the cement stone, we have proposed the use of calcium polysulfide, solutions of which are successfully used in construction as an impregnation, and acting as a protective film. Calcium polysulfide in the processing of concrete products reduces permeability, increases the strength of concrete and frost resistance, which is convincingly shown in [20,21].

The idea of using calcium polysulfide in cement slurries was that when depositing in the pores of the stone, it forms a protective coating of hydrophobic sulfur nanoparticles, which will ensure the inhibition of pore space. In addition, the rate of diffusion of aggressive ions inside the cement stone will slow down.

During the experiments, three methods were tested to introduce liquid calcium polysulfide into the cement slurries: into the tempering fluid (water), directly into the prepared cement slurry and dry method, through cement powder, which was subsequently subjected to disintegrator treatment.

The effect of calcium polysulfide on the rheological properties of cement slurry and stone

At this stage of the study, calcium polysulfide at a concentration of $0-5 \%$ by weight of cement was injected directly into the cement slurry prepared from the plugging Portland cement PCT-I-50, with a water-cement ratio of 0.45 . To determine the rheological properties of cement slurries (plastic viscosity $\eta$ and dynamic shear stress to), the atmospheric OFITE Model 900 viscometer was used. In addition, taking into account the technological features of cement slurry injection, they determined the static shear stress (SNS) after 10 seconds and 10 minutes [1,25]. The spreadability of the cement slurry (2R), measured by the AzNII cone, was also monitored (Table 1).

Experiments show of that calcium polysulfide has no significant effect on the rheological properties of cement slurries.

Since the time of the moveable state of the cement slurry during the ce-menting of wells can reach up to 4-5 hours, for these systems the most important indicator is the pumpability determined by the consistometer [1]. In this case, the effectiveness of various methods for the input of calcium polysulfide into cement slurries were tested (Table 2).

\section{Table 1}

The effect of calcium polysulfide on the rheological properties of cement slurry

\begin{tabular}{|c|c|c|c|c|c|c|}
\hline \multirow{2}{*}{ № } & \multirow{2}{*}{$\begin{array}{c}\text { Calcium } \\
\text { polysulfide, } \%\end{array}$} & \multicolumn{5}{|c|}{ Weight indices } \\
\cline { 5 - 7 } & & $\mathbf{\eta}, \mathbf{m P a} \cdot \mathbf{s}$ & $\boldsymbol{\tau}_{\mathbf{o}}, \mathbf{d P a}$ & $\begin{array}{c}\text { Gel strength } \\
\mathbf{d P a} \text { sec }\end{array}$ & $\begin{array}{c}\text { Gel strength } \\
\mathbf{1 0 \text { min}}\end{array}$ & \multirow{2}{*}{$\mathbf{2 R}, \mathbf{c m}$} \\
\hline 1 & 0 & 68,5 & 10,0 & 8 & 10 & 22 \\
\hline 2 & 1 & 63,5 & 10,8 & 9 & 12 & 22 \\
\hline 3 & 3 & 63,1 & 10,5 & 9 & 14 & 24 \\
\hline 4 & 5 & 62,6 & 10,6 & 8 & 15 & 24 \\
\hline
\end{tabular}


Table 2

The effect of calcium polysulfide on the pumpability of cement slurry

\begin{tabular}{|c|c|c|c|c|}
\hline \multirow{2}{*}{ № } & \multirow{2}{*}{$\begin{array}{c}\text { Calcium } \\
\text { polysulfide, \% }\end{array}$} & \multicolumn{3}{|c|}{$\begin{array}{c}\text { The pumpability of the cement slurry, hour, } \\
\text { with the input of calcium polysulfide }\end{array}$} \\
\cline { 3 - 5 } & & $\begin{array}{c}\text { into the tempering fluid } \\
\text { (water) }\end{array}$ & into the cement slurry & through cement powder \\
\hline 1 & 0 & 4 & 4 & 3 \\
\hline 2 & 1 & 5 & 5 & 4 \\
\hline 3 & 3 & 5,9 & 6 & 4,5 \\
\hline 4 & 5 & 6,4 & 6,5 & 5 \\
\hline
\end{tabular}

Increased concentration of calcium polysulfide in cement slurry rises the time of its pumpability. When the additive is introduced into the tempering fluid or in the cement slurry, the allowable pumping time the solution is almost the same, but when input the reagent through the disintegrator, this value is already $1-1.5$ hours less. The processes occurring with cement during its disintegrating treatment play an important role in accelerating the structure formation of solutions [22].

The effects of calcium polysulfide on the strength characteristics of cement stone are given in table 3 .

Introduction of the calcium polysulfide to the composition of the cement slurry increases the strength of the cement stone. Moreover, with increased concentration of it in the solution, the compressive and flexural strength becomes significantly higher. For example, in the sample with a $5 \%$ additive, the flexural strength increased by 2 times compared with the original sample, and the compressive strength increased by 1.23 times. The reason for increasing the strength of cement stone, perhaps, is the clogging of its pores.

This assumption was proved by the results of the evaluation of the permea-bility of cement stone at the age of three days, given in Table 4.

When calcium polysulfide was added to the cement mortar, the permea-bility of the cement stone dropped sharply (more than 2 times for the sample from 5\%) compared to the control sample, which proves a change in the structure of the pore space of the cement stone.

Since most types of corrosion of cement stone under the action of aggressive fluids are controlled by the diffusion of the aggressor deep into the stone, the change in the structure should significantly affect the rate of corrosion processes.

\section{Table 3}

The effect of calcium polysulfide on the strength of cement stone

\begin{tabular}{|c|c|c|c|c|c|c|}
\hline \multirow{2}{*}{ Weight indices } & \multicolumn{5}{|c|}{ The strength of the stone, MPa, with the addition of calcium polysulfide, \% } \\
\cline { 2 - 7 } & $\mathbf{0}$ & $\mathbf{1}$ & $\mathbf{2}$ & $\mathbf{3}$ & $\mathbf{4}$ & $\mathbf{5}$ \\
\hline $\begin{array}{c}\text { Flexural } \\
\text { strength }\end{array}$ & 1,16 & 1,16 & 1,29 & 1,41 & 2,14 & 2,32 \\
\hline $\begin{array}{c}\text { Compressive } \\
\text { strength }\end{array}$ & 20,9 & 21,2 & 21,8 & 24,5 & 25,0 & 25,6 \\
\hline
\end{tabular}

\section{Table 4}

The effect of calcium polysulfide on the permeability of cement stone

The permeability of cement stone, $\mathrm{mD}$, with the addition of calcium polysulfide, $\%$

\begin{tabular}{|c|c|c|c|}
\hline $\mathbf{0}$ & $\mathbf{1}$ & $\mathbf{3}$ & $\mathbf{5}$ \\
\hline 0,34 & 0,2 & 0,18 & 0,14 \\
\hline
\end{tabular}




\author{
Effect of calcium polysulfide on acid corrosion of ce- \\ ment stone
}

In the experiments, the aggressive medium was represented by a one-molar solution of hydrochloric acid $(\mathrm{HCl})$ with a ratio of the volumes of the acid so-lution to the volume of cement stone samples 10: 1 . The watercement ratio of the solution is 0.4 , the cement grade PCT-I-50, the age of the samples prior to installation in an aggressive environment is three days. Replacement of the corrosive medium was carried out in three days with the duration of the experiment of 35 days. Every 7 days from the corrosive environment there were selected samples for research.

It was also assumed as the temperature of sample formation increases, calcium polysulfide may melt and, spreading, will cover a large surface of the pores, increasing the degree of their inhibition. For this, a part of the samples with the concentration of the additive of $3 \%$ and $5 \%$ were subjected to boiling in water for two hours. This experiment partially modeled the working conditions of cement stone in wells at bottomhole temperatures close to $100^{\circ} \mathrm{C}$, corresponding to depths of more than $4000 \mathrm{~m}$.

After the end of the experiment, the following results were obtained.

1. Samples of additive-free cement during the test completely collapsed.

$\mathbf{a}$

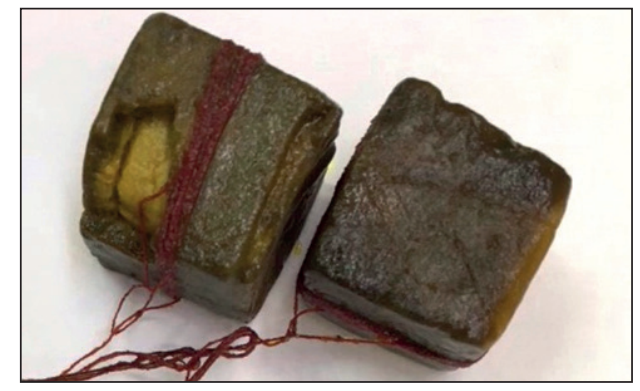

b

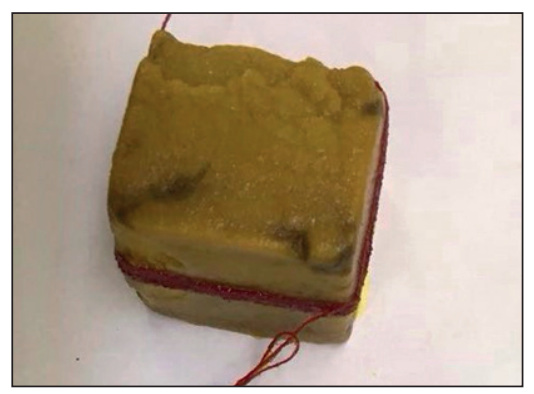

Fig. 1. Cement stone samples after acid corrosion: a - the content of calcium polysulfide $-3 \%$; b - the content of calcium polysulfide $-5 \%$
2. Samples of cement with the addition of $1 \%$ calcium polysulfide were almost completely destroyed during the test.

3. Samples of cement with the addition of $3 \%$ calcium polysulfide during the experiment were partially destroyed (Fig. 1a). The corner of on one sample a «corroded» layer broke off.

4. Samples of cement with the addition of $5 \%$ calcium polysulfide were practically not corroded during the test, except for the breakaway angle (Fig. 1b).

5. Samples of cement with the addition of $3 \%$ calcium polysulfide, subjected to two-hour boiling, after 35 days of testing did not collapse and practically did not undergo corrosion. Cracking and delamination were not observed (Fig. 2a).

6. Samples of cement with the addition of $5 \%$ calcium polysulfide, sub-jected to two-hour boiling, after 35 days of testing did not collapse and did not undergo corrosion (Fig. 2b).

Prior to placing the samples in an aggressive environment, the permeability of the cement stone was measured, and during the experiment the corrosion depth of the test samples was determined (Table 5).

The experiments carried out confirmed both the positive effect of calcium polysulfide on the kinetics acid corrosion of cement stone. And the assumption of inhibition of the surface of the pores with molten sulfur.

a

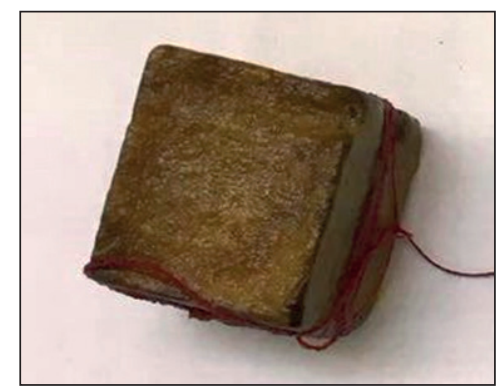

b

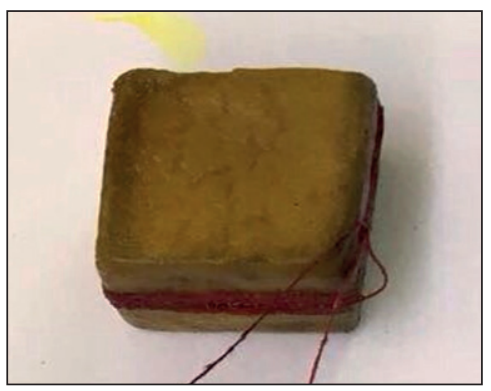

Fig. 2. Cement stone samples boiled after acid corrosion: a - the content of calcium polysulfide $-3 \%$;

b - the content of calcium polysulfide $-5 \%$ 
Table 5

Summary of acid corrosion research

\begin{tabular}{|c|c|c|c|c|c|c|}
\hline \multirow{2}{*}{ № } & \multirow{2}{*}{$\begin{array}{c}\text { Calcium } \\
\text { polysulfide, \% }\end{array}$} & \multirow{2}{*}{$\begin{array}{c}\text { Permeability of the stone } \\
\text { at the age of 2 days, } \mathbf{m D}\end{array}$} & \multicolumn{4}{|c|}{ Depth of corrosion, mm through, days } \\
\cline { 4 - 7 } & & $\mathbf{7}$ & $\mathbf{1 4}$ & $\mathbf{2 1}$ & $\mathbf{3 5}$ \\
\hline 1 & 0 & 0,35 & 5 & 8 & 30 & - \\
\hline 2 & 1 & 0,2 & 5 & 10 & 18 & 30 \\
\hline 3 & 3 & 0,18 & 3 & 5 & 6 & 10 \\
\hline 4 & 5 & 0,14 & 3 & 5 & 6 & 9 \\
\hline 5 & $3+$ boiling & 0,14 & 2 & 3 & 5 & 7 \\
\hline 6 & $5+$ boiling & 0,12 & 2 & 3 & 5 & 6 \\
\hline
\end{tabular}

The effect of calcium polysulfide on hydrogen sulfide corrosion of cement stone

The final stage of the experiments was the studies of corrosion of a cement stone when exposed to hydrogen sulfide dissolved in water with a concentration of $3000 \mathrm{mg} / 1$.

In the experiment, seven cement slurries were used: without additives; with calcium polysulfide at a concentration of $1 \%, 3 \%, 5 \%$ input method - in the ce-ment slurry; with calcium polysulfide in the same concentrations, the input method is through the cement powder. Cement grade PCT-I-50, W/C $=0.4$, sample size 40x40x40 mm.

Fig. 3 and 4 show photos of the samples after 45 days in an aggressive environment.
In tab. 6 the results of hydrogen sulfide corrosion of cement stone samples are summarized.

The results of the experiment, confirmed that calcium polysulfide has anti-corrosion properties against aggressive media. With an increase in the concentra-tion of the additive in the solution, the penetration depth of aggressive components decreases, therefore, the corrosion process is significantly slowed down.

Micrographs samples of cement stone, presented in Fig. 5. It was shown that calcium polysulfide, being distributed in the pore space, blocks their surface, limiting the contact of aggressive ions with hardening products.

Micrographs clearly show that calcium polysulfide fills the pore space of the cement stone during its hardening and does not allow components of the corrosive medium to penetrate into the stone and destroy it.

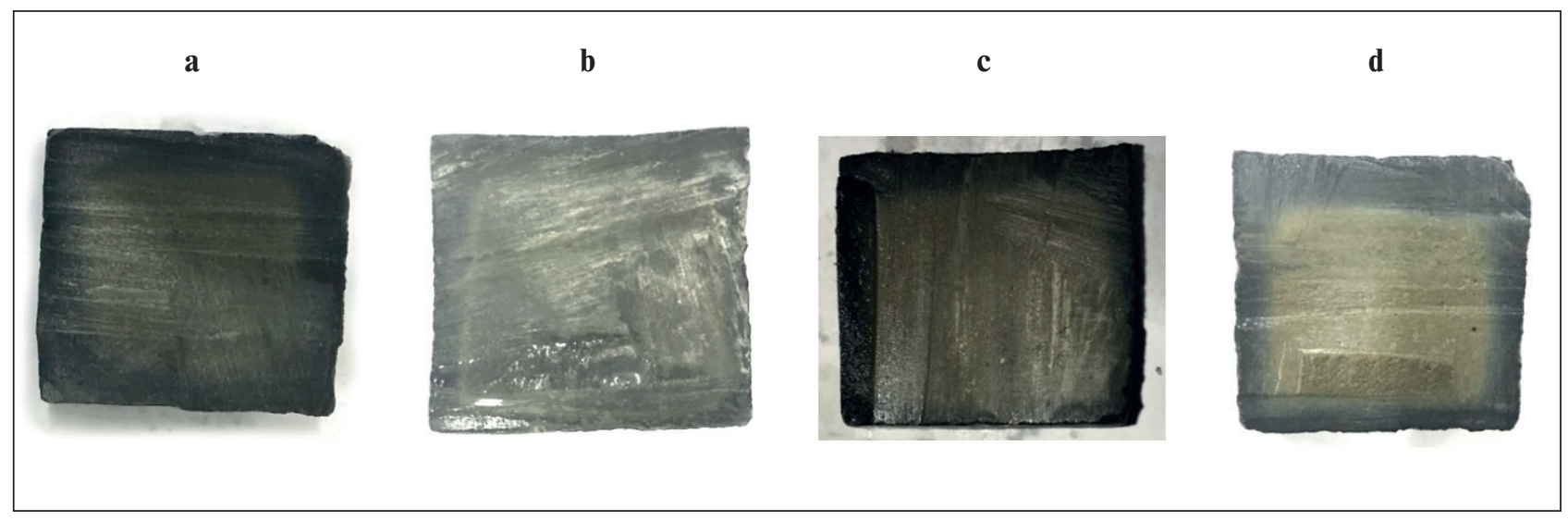

Fig. 3. Samples of cement stone after corrosion in dissolved hydrogen sulfide:

a - a sample of additive-free cement;

b - a sample of cement with $1 \%$ calcium polysulfide, input additives in the solution;

c - a sample of cement with $3 \%$ calcium polysulfide, input additives in the solution;

d - a sample of cement with $5 \%$ calcium polysulfide, input additives in the solution 


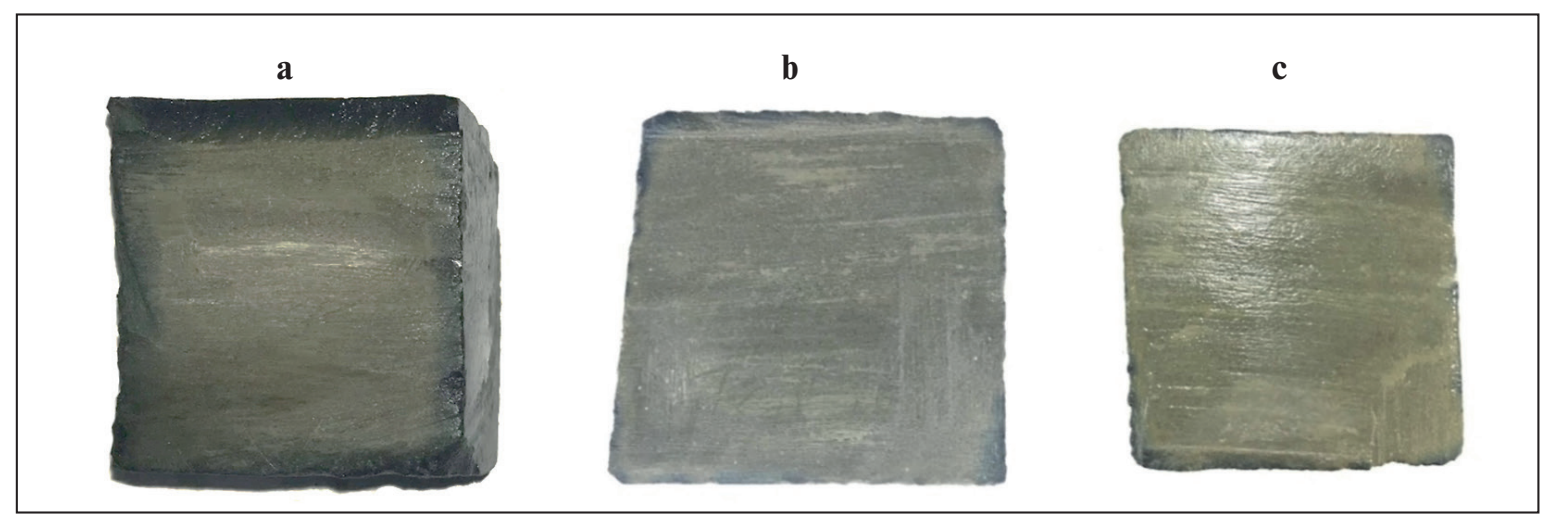

Fig. 4. Samples of cement stone after corrosion in hydrogen sulfide dissolved in water:

a - a sample of cement with $1 \%$ calcium polysulfide, the input of the additive through a disintegrator;

b - a sample of cement with 3\% calcium polysulfide, the input of the additive through cement powder;

$\mathrm{c}$ - a sample of cement with $5 \%$ calcium polysulfide, the input of the additive - through cement powder

Table 6

Generalized data on the study of hydrogen sulfide corrosion

\begin{tabular}{|c|c|c|c|}
\hline Calcium polysulfide, $\%$ & $\begin{array}{c}\text { Input method of calcium } \\
\text { polysulfide }\end{array}$ & Depth of corrosion, mm & $\begin{array}{c}\text { Volume of corroded cement } \\
\text { stone, } \mathrm{mm}^{3}\end{array}$ \\
\hline 0 & - & 6 & 324 \\
\hline 1 & in cement slurry & 5 & 270 \\
\hline 3 & in cement slurry & 4 & 216 \\
\hline 5 & in cement slurry & 4,5 & 243 \\
\hline 1 & through cement powder & 3 & 162 \\
\hline 3 & through cement powder & 2 & 108 \\
\hline 5 & through cement powder & 0,3 & 16,2 \\
\hline
\end{tabular}

$\mathbf{a}$

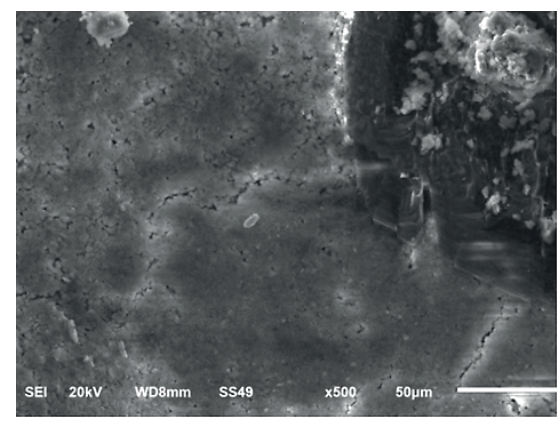

Fig. 5. Micrographs of cement stone samples: $\mathrm{a}$ - pore space near the grain of cement x 500 ; b - time of cement stone $x$ 2000;

$\mathrm{c}$ - pore space filled with calcium polysulfide $\mathbf{x} 500$; d - calcium polysulfide crystals x 2000 c

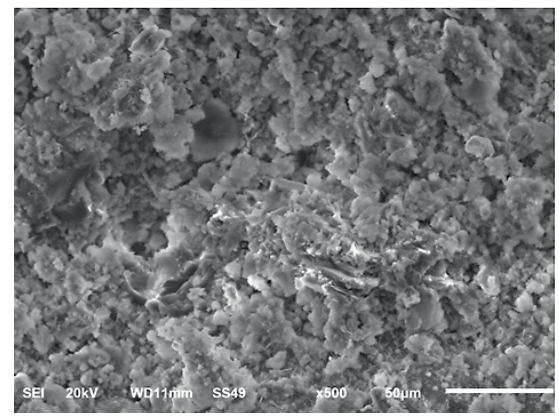

b

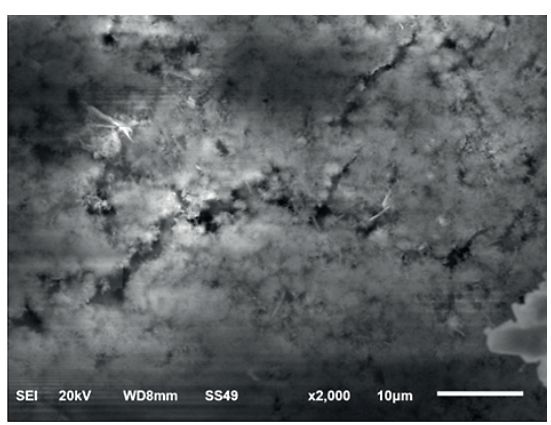

d

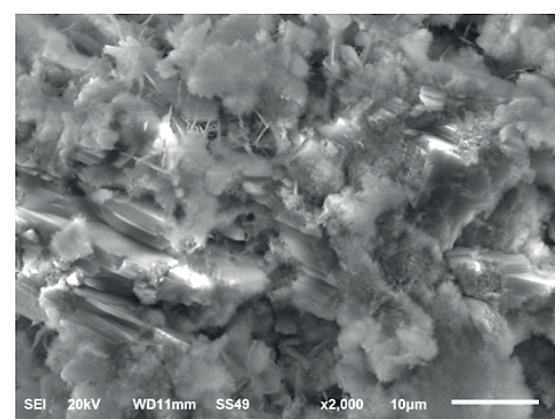




\section{CONCLUTION}

1. The use of calcium polysulfide in cement slurries is an effective way to increase the durability of cement stone when exposed to aggressive fluids, due to clogging of the pores and inhibiting their surface.

2. Calcium polysulfide does not impair the rheological properties of cement slurries and their pumpability, allowing for normal casing cementing processes.
3. The addition of calcium polysulfide to cement mortars increases the strength and reduces the permeability of the resulting cement stone.

4. The most effective is the technology of introduction of calcium polysulfide into dry cementing material with its subsequent disintegrator processing.

5. The revealed features of the change in the properties of the mortar and stone based on the Portland cement show the prospect of using calcium polysulfide nanoadditives to obtain durable concrete structures.

\section{ВВЕДЕНИЕ}

A грессивное влияние на цементный камень проявляют все без исключения кислоты и многочисленные соли. Пластовые воды многих месторождений содержат различные растворенные соли и являются крайне агрессивными по отношению к тампонажному камню $[1,2]$.

Анализ различных видов коррозии [3-8] показывает, что кинетика многих их них определяется диффузией агрессивных ионов внутрь камня. Это относится к коррозии под действием кислых сред, сульфатной, магнезиальной коррозии. При коррозии выщелачивания кинетика диффузии ионов кальция из цементного камня также имеет диффузный контроль.

Из практики промышленного и гражданского строительства для повышения долговечности конструкций известно применение плотных бетонов с пониженным водоцементным отношением (В/Ц) или пропитка изделий специальными составами [9-11].

При строительстве скважин данные технологии неприемлемы, поскольку для цементирования используются растворы на основе цемента и воды, при В/Ц 0,45-0,9, иногда содержащие модифицирующие добавки. Снижение водоцементного отношения тампонажных растворов ведет к повышению плотности раствора и может привести к осложнениям или авариям при цементировании. Кроме того, снижение В/Ц раствора приводит к потере его подвижности, а применение пластификаторов может вызвать седиментационное расслоение раствора $[1,12]$.

Использование пропиточных материалов для повышения долговечности цементного камня в скважинных условиях невозможно, поскольку используемая при цементировании скважин цементоводная суспензия в течение 1-4 часов прокачивается внутри обсадных труб и по затрубному пространству при небольших диаметрах труб и малых (15-20 мм) кольцевых зазорах на глубинах несколько километров.

Для крепи скважин, состоящей из обсадной колонны и цементного кольца небольшой толщины, наиболее слабым звеном является цементный камень, который работает в постоянном контакте с агрессивными пластовыми флюидами и уязвим к их воздействию.

В статье представлены результаты исследования влияния наноразмерных частиц полисульфида кальция на свойства цементного камня, применяемого при креплении нефтяных и газовых скважин. В рамках исследований были проведены эксперименты по оценке воздействия полисульфида кальция на цементные растворы и полученный камень, его стойкость в сероводородной среде. Электронная микроскопия позволила оценить влияние наноразмерных частиц полисульфида кальция на повышение коррозионной стойкости цементного камня.

\section{ОСНОВНАЯ ЧАСТЬ}

Теоретические аспекты сероводородной коррозии цементного камня

Сероводород, количество которого в пластовом газе может доходить до 25\%, является наиболее агрессивным компонентом пластовых флюидов $[13,14,15]$. Механизм поражения и факторы, определяющие кинетику процесса, подробно описаны в работах $[1,2,7,13-15]$. Условиями разрушения камня при газовой сероводородной агрессии является высокая пористость камня, обеспечивающая проникновение агрессора в глубь камня, и высокий рН продуктов твердения, обеспечивающий образование малорастворимого сульфида кальция. Накопление последнего и приводит к развитию растягивающих напряжений в цементном камне. Вторичным фактором появления растягивающих напряжений мо- 
жет явиться образование эттрингита при переходе сульфидной серы в сульфатную. Наиболее уязвимым к газообразному сероводороду является камень из портландцемента, тогда как образцы камня c pH $\leqslant 11$, полученные из шлаковых вяжущих при высоких температурах, оказались стойкими $[14,16]$.

При воздействии растворенного сероводорода на цементный камень наблюдается коррозия первого типа (по Москвину В.М.) [3, 4, 13, 14], причем образцы камня из всех видов вяжущих, за исключением кислотоупорного цемента, разрушаются, и речь идет только о скорости процесса. При этом процесс поражения имеет послойный характер, присущий кислотной коррозии.

Кинетика процесса коррозии определяется концентрацией агрессивной среды на границе с цементным камнем, составом и плотностью слоя продуктов коррозии, реакционной емкостью цементного камня, и может описываться различными кинетическими кривыми [17].

Для цементного камня глубоких скважин, когда скорость подвода агрессивного агента к поверхности образца больше, чем его диффузия в порах камня, наиболее эффективным способом замедления коррозии является управление структурой порового пространства, что и стало основной задачей исследований.

К сожалению, технологические приемы, широко применяемые в строительстве, практически невозможно использовать при цементировании обсадных колонн в глубоких скважинах, хотя работы в этом направлении проводились. В частности, можно отметить работу [18], в которой описан опыт применения метода химического конденсирования микродисперсных частиц в порах камня. Подобный эффект наблюдается и при использовании добавок нанокремнезема [19].

Нами для снижения пористости цементного камня предложено применение полисульфида кальция, растворы которого успешно применяются в строи- тельстве в качестве пропитки, действующей в роли защитной пленки. Полисульфид кальция при обработке бетонных изделий уменьшает проницаемость, повышает прочность бетона и морозостойкость, что убедительно доказано в работах [20, 21].

Идея применения полисульфида кальция в тампонажных растворах состоит в том, что он, осаждаясь в порах камня, образует защитное покрытие из гидрофобных наночастиц серы, которые будут обеспечивать ингибирование порового пространства. Кроме того, будет замедляться скорость диффузии агрессивных ионов внутрь цементного камня.

При проведении экспериментов было использовано три способа введения жидкого полисульфида кальция в цементный раствор: в жидкость затворения (воду), в приготовленный цементный раствор и сухой способ, в порошок цемента, подвергаемый впоследствии дезинтеграторной обработке. Результаты экспериментов показали, что последний способ оказался самым эффективным.

Влияние полисульфида кальция на реологические свойства цементного раствора и камня

На этом этапе исследований полисульфид кальция в концентрации от 0 до 5\% от массы цемента вводился непосредственно в цементный раствор, приготовленный из тампонажного портландцемента ПЦТ-I-50, при водоцементном отношении 0,45. Для определения реологических свойств тампонажных растворов (пластическая вязкость ұ и динамическое напряжение сдвига то) использовался атмосферный вискозиметр OFITE Model 900. Кроме того, с учетом технологических особенностей закачки тампонажных растворов, у них определялось статическое напряжение сдвига (CHC) через 10 секунд и 10 минут $[1,25]$. Также контролировалась растекаемость цементного раствора (2R), замеряемая по конусу АзНИИ (табл. 1).

\section{Таблица 1}

\section{Влияние полисульфида кальция на реологические свойства цементного раствора}

\begin{tabular}{|c|c|c|c|c|c|c|}
\hline \multirow[b]{2}{*}{ № } & \multirow{2}{*}{$\begin{array}{c}\text { Полисульфид } \\
\text { кальция, \% }\end{array}$} & \multicolumn{5}{|c|}{ Показатели } \\
\hline & & $\eta$, мПа •с & $\tau_{\mathrm{o}}$, дПа & $\begin{array}{c}\mathrm{CHC}_{10 \text { сек}}, \\
\text { дПа }\end{array}$ & $\begin{array}{c}\mathrm{CHC}_{10 \text { мин }}, \\
\text { дПа }\end{array}$ & $2 \mathrm{R}, \mathrm{cm}$ \\
\hline 1 & 0 & 68,5 & 10,0 & 8 & 10 & 22 \\
\hline 2 & 1 & 63,5 & 10,8 & 9 & 12 & 22 \\
\hline 3 & 3 & 63,1 & 10,5 & 9 & 14 & 24 \\
\hline 4 & 5 & 62,6 & 10,6 & 8 & 15 & 24 \\
\hline
\end{tabular}


CONCRETE AND MORTARS MODIFIED BY NANOSIZE ADDITIVES • БETOНЫ И РАСТВОРЫ, МОДИФИЦИРОВАННЫЕ НАНОРАЗМЕРНЫМИ ДОБАВКАМИ

Таблица 2

Влияние полисульфида кальция на прокачиваемость цементного раствора

\begin{tabular}{|c|c|c|c|c|}
\hline \multirow{2}{*}{ № } & \multirow{2}{*}{ Добавка, \% } & \multicolumn{3}{|c|}{ Прокачиваемость цементного раствора, час, при вводе полисульфида кальция } \\
\cline { 3 - 5 } & & в жидкость затворения & в цементный раствор & через дезинтегратор \\
\hline 1 & 0 & 4 & 4 & 3 \\
\hline 2 & 1 & 5 & 5 & 4 \\
\hline 3 & 3 & 5,9 & 6 & 4,5 \\
\hline 4 & 5 & 6,4 & 6,5 & 5 \\
\hline
\end{tabular}

Эксперименты показали, что полисульфид кальция не оказывает существенного влияния на реологические свойства тампонажных растворов.

Поскольку время подвижного состояния цементного раствора при креплении скважин может доходить до 4-5 часов, то для этих систем важнейшим показателем является прокачиваемость, определяемая консистометром [1]. При этом была проверена эффективность различных способов ввода полисульфида кальция в цементные растворы (табл. 2).

Повышение концентрации полисульфида кальция в цементном растворе увеличивает время его прокачиваемости. При вводе добавки в жидкость затворения или в цементный раствор допустимое время прокачивания раствора практически одинаково, но при вводе реагента через дезинтегратор это значение уже на 1-1,5 часа меньше. Мы полагаем, что в ускорении структурообразования растворов важную роль играют процессы, происходящие с цементом при его дезинтеграторной обработке [22].
Влияние полисульфида кальция на прочностные показатели цементного камня приведены в табл. 3.

Введение в состав цементного раствора полисульфида кальция повышает прочность полученного камня. Более того, с увеличением его концентрации в растворе прочность на сжатие и изгиб становится существенно выше. К примеру, у образца с 5\% добавкой прочность на изгиб возросла в 2 раза по сравнению с исходным образцом, а прочность на сжатие увеличилась в 1,23 раза. Причиной повышения прочности цементного камня, возможно, является кольматация его пор.

Подтверждением данного предположения явились результаты оценки проницаемости цементного камня в возрасте трех суток, приведенные в табл. 4.

При добавке полисульфида кальция в цементный раствор проницаемость цементного камня резко снизилась (более чем в 2 раза для образца с 5\%) по сравнению с контрольным образцом, что доказы-

Таблица 3

Влияние полисульфида кальция на прочность цементного камня

\begin{tabular}{|c|c|c|c|c|c|c|}
\hline \multirow{2}{*}{ Показатели } & \multicolumn{5}{|c|}{ Предел прочности камня, МПа, при добавке полисульфида кальция, \% } \\
\cline { 2 - 7 } & $\mathbf{0}$ & $\mathbf{1}$ & $\mathbf{2}$ & $\mathbf{3}$ & $\mathbf{4}$ & $\mathbf{5}$ \\
\hline При изгибе & 1,16 & 1,16 & 1,29 & 1,41 & 2,14 & 2,32 \\
\hline При сжатии & 20,9 & 21,2 & 21,8 & 24,5 & 25,0 & 25,6 \\
\hline
\end{tabular}

Таблица 4

Влияние полисульфида кальция на проницаемость цементного камня

\begin{tabular}{|c|c|c|c|}
\hline \multicolumn{4}{|c|}{ Проницаемость цементного камня, мД, при добавке сульфидной серы, \% } \\
\hline $\mathbf{0}$ & $\mathbf{1}$ & $\mathbf{3}$ & $\mathbf{5}$ \\
\hline 0,34 & 0,2 & 0,18 & 0,14 \\
\hline
\end{tabular}


вает изменение структуры порового пространства цементного камня.

Поскольку большинство видов коррозии цементного камня при действии агрессивных флюидов контролируется диффузией агрессора в глубь камня, то изменение структуры последнего должно существенно повлиять на скорость коррозионных процессов.

\section{Влияние полисульфида кальция на кислотную кор-} розию цементного камня

В экспериментах агрессивная среда была представлена одномолярным раствором соляной кислоты $(\mathrm{HCl})$ при соотношении объемов раствора кислоты к объему образцов цементного камня 10:1. Водоцементное отношение раствора 0,4 , марка цемента ПЦТ-I-50, возраст образцов до установки в агрессивную среду - трое суток. Замена агрессивной среды проводилась через трое суток при продолжительности эксперимента 35 суток. Через каждые 7 суток из агрессивной среды отбирались образцы для исследований.

Предполагалось также, что при повышении температуры формирования образцов полисульфид кальция может расплавиться и, растекаясь, покроет большую поверхность пор, увеличив степень их ингибирования. Для этого часть образцов с концентрацией добавки $3 \%$ и 5\% были подвергнуты кипячению в воде в течение двух часов. Данный эксперимент частично моделировал условия работы цементного камня в скважинах

$\mathbf{a}$

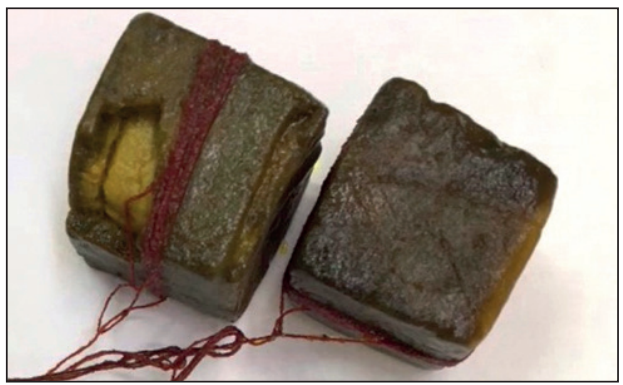

б

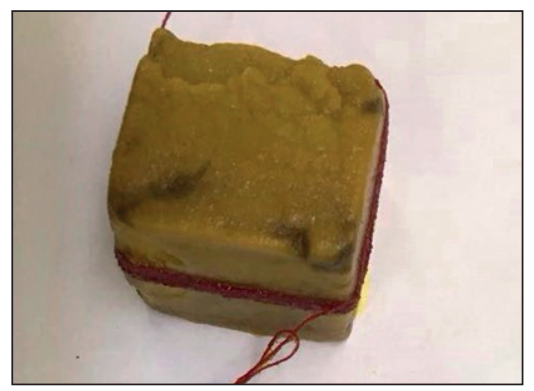

Рис. 1. Образцы цементного камня после кислотной коррозии:

a - содержание полисульфида кальция - 3\%;

б - содержание полисульфида кальция - 5\% при забойных температурах, близких к $100^{\circ} \mathrm{C}$, соответствующих глубинам более 4000 м.

После окончания эксперимента были получены следующие результаты:

1. Образцы из бездобавочного цемента в ходе испытания полностью разрушились.

2. Образцы из цемента с добавкой $1 \%$ полисульфида кальция в ходе испытания разрушились практически полностью.

3. Образцы из цемента с добавкой $3 \%$ полисульфида кальция в ходе эксперимента частично разрушились (рис. 1а). На одном образце в углу откололся «прокорродированный» слой.

4. Образцы из цемента с добавкой $5 \%$ полисульфида кальция в ходе испытания практически не подверглись коррозии, за исключением отколовшегося угла (рис. 1б).

5. Образцы из цемента с добавкой $3 \%$ полисульфида кальция, подвергнутые двухчасовому кипячению, после 35 суток испытаний не разрушились и практически не подверглись коррозии. Растрескивания и расслаивания не наблюдалось (рис. 2a).

6. Образцы из цемента с добавкой 5 \% полисульфида кальция, подвергнутые двухчасовому кипячению, после 35 суток испытаний не разрушились и не подверглись коррозии (рис. 2б).

До установки образцов в агрессивную среду была измерена проницаемость цементного камня, а в ходе

a

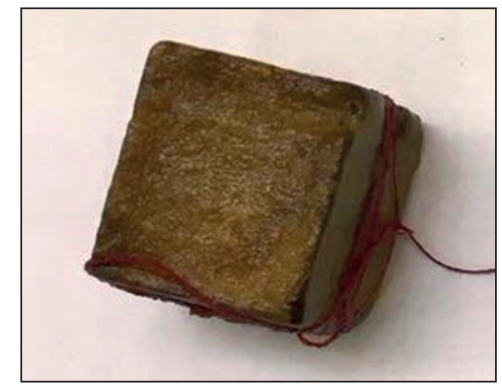

б

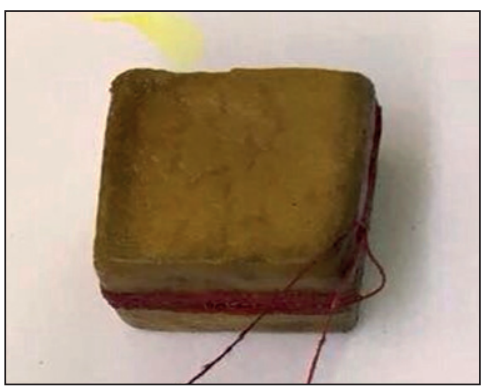

Рис. 2. Образцы цементного камня, подвергнутые кипячению после кислотной коррозии:

a - содержание полисульфида кальция - 3\%;

б - содержание полисульфида кальция - 5\% 
CONCRETE AND MORTARS MODIFIED BY NANOSIZE ADDITIVES • БETOНЫ И РАСТВОРЫ, МОДИФИЦИРОВАННЫЕ НАНОРАЗМЕРНЫМИ ДОБАВКАМИ

Таблииа 5

Обобщенные данные по исследованию кислотной коррозии

\begin{tabular}{|c|c|c|c|c|c|c|}
\hline \multirow{2}{*}{ № } & \multirow{2}{*}{$\begin{array}{c}\text { Добавка полисульфида } \\
\text { кальция, \% }\end{array}$} & \multirow{2}{*}{$\begin{array}{c}\text { Проницаемость камня } \\
\text { в возрасте 2 сут, мД }\end{array}$} & \multicolumn{4}{|c|}{ Глубина коррозии, мм через, сут } \\
\cline { 4 - 7 } & 0 & 0,35 & $\mathbf{7}$ & $\mathbf{1 4}$ & $\mathbf{2 1}$ & $\mathbf{3 5}$ \\
\hline 1 & 1 & 0,2 & 5 & 10 & 18 & 30 \\
\hline 3 & 3 & 0,18 & 3 & 5 & 6 & 10 \\
\hline 4 & 5 & 0,14 & 3 & 5 & 6 & 9 \\
\hline 5 & $3+$ кипячение & 0,14 & 2 & 3 & 5 & 7 \\
\hline 6 & $5+$ кипячение & 0,12 & 2 & 3 & 5 & 6 \\
\hline
\end{tabular}

эксперимента определялась глубина коррозии испытуемых образцов (табл. 5).

Проведенные эксперименты подтвердили положительное влияние полисульфида кальция на кинетику кислотной коррозии цементного камня. Также получило подтверждение предположение об ингибировании поверхности пор расплавом серы.

Влияние полисульфида кальция на сероводородную коррозию цементного камня

Завершающим этапом экспериментов стало исследование коррозии цементного камня при воздействии растворенного в воде сероводорода с концентрацией 3000 мг/л.

В эксперименте было использовано семь рецептур цементного раствора: без добавок; с полисульфидом кальция при концентрации 1\%, 3\%, $5 \%$ ме- тод ввода - в цементный раствор; с полисульфидом кальция в тех же концентрациях метод ввода - через дезинтегратор. Марка цемента - ПЦТ-I-50, В/Ц = 0,4, размер образцов - 40х40х40 мм.

На рис. 3, 4 представлены фото образцов после 45 суток пребывания в агрессивной среде.

В табл. 6 представлены обобщенные результаты по исследованию сероводородной коррозии образцов цементного камня.

Результаты эксперимента подтвердили, что полисульфид кальция обладает антикоррозионными свойствами по отношению к агрессивным средам. С увеличением концентрации добавки в растворе снижается глубина проникновения агрессивных компонентов, следовательно, существенно замедляется процесс коррозии.

Микрофотографии образцов цементного камня, представленные на рис. 5, показали, что полисуль- a

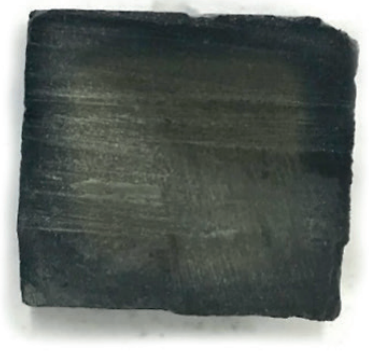

б

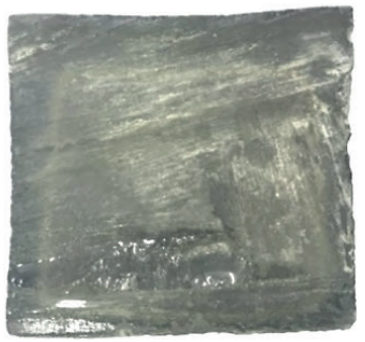

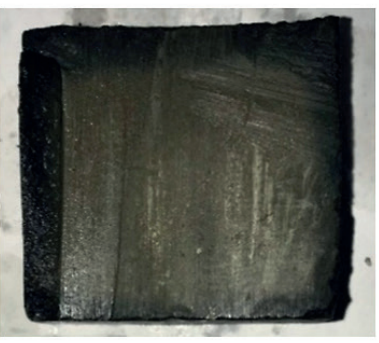

Г

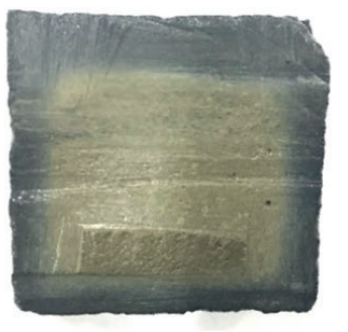

Рис. 3. Образцы цементного камня после коррозии в растворенном в воде сероводороде:

a - образец из бездобавочного цемента;

б - образец из цемента с $1 \%$ полисульфида кальция, ввод добавки в раствор;

в - образец из цемента с 3\% полисульфида кальция, ввод добавки в раствор;

г - образец из цемента с 5\% полисульфида кальция, ввод добавки в раствор 


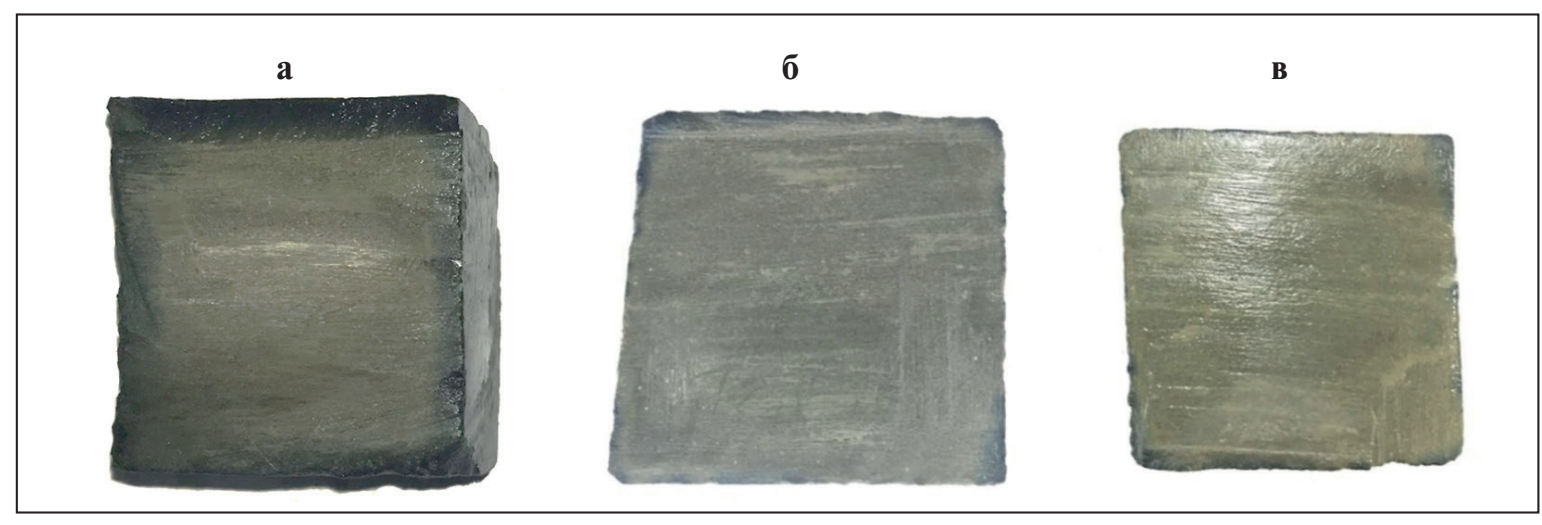

Рис. 4. Образцы цементного камня после коррозии в растворенном в воде сероводороде: a - образец из цемента с $1 \%$ полисульфида кальция, ввод добавки - через дезинтегратор, б - образец из цемента с 3\% полисульфида кальция, ввод добавки - через дезинтегратор, в - образец из цемента с 5\% полисульфида кальция, ввод добавки - через дезинтегратор

\section{Таблица 6}

Обобщенные данные по исследованию сероводородной коррозии

\begin{tabular}{|c|c|c|c|}
\hline $\begin{array}{c}\text { Концентрация полисуль- } \\
\text { фида кальция, \% }\end{array}$ & $\begin{array}{c}\text { Метод ввода полисульфида } \\
\text { кальция }\end{array}$ & \begin{tabular}{c} 
Глубина коррозии, мм \\
\hline 0
\end{tabular}$\quad-\quad \begin{array}{c}\text { Объем прокорродированного } \\
\text { цементного камня, мм }\end{array}$ \\
\hline 1 & в цементный раствор & 5 & 324 \\
\hline 3 & в цементный раствор & 4 & 270 \\
\hline 5 & в цементный раствор & 4,5 & 243 \\
\hline 1 & через дезинтегратор & 3 & 162 \\
\hline 3 & через дезинтегратор & 2 & 108 \\
\hline 5 & через дезинтегратор & 0,3 & 16,2 \\
\hline
\end{tabular}

Рис. 5. Микрофотографии образцов цементного камня:

а - поровое пространство около зерна цемента х 500; б - пора цементного камня х 2000; в - поровое пространство, заполненное полисульфидом кальция x 500; г - кристаллы полисульфида кальция x 2000
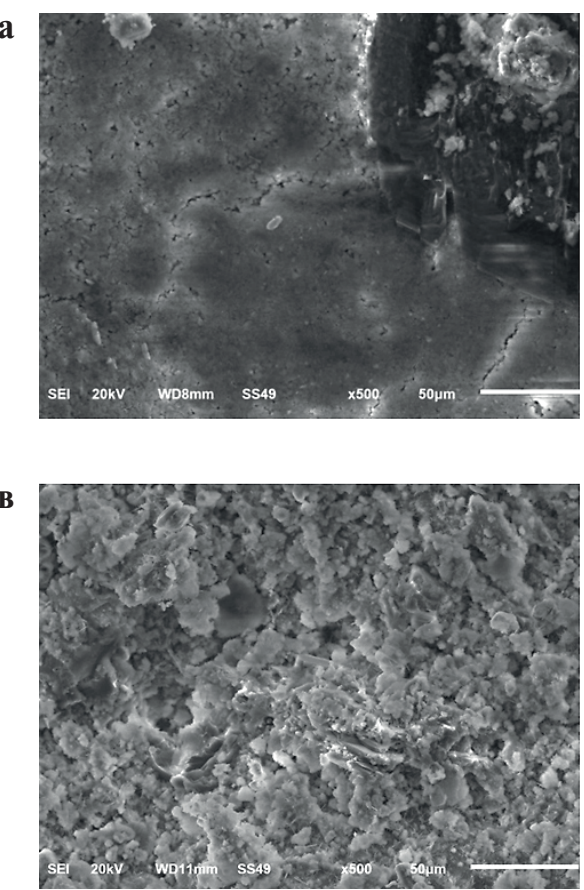

б

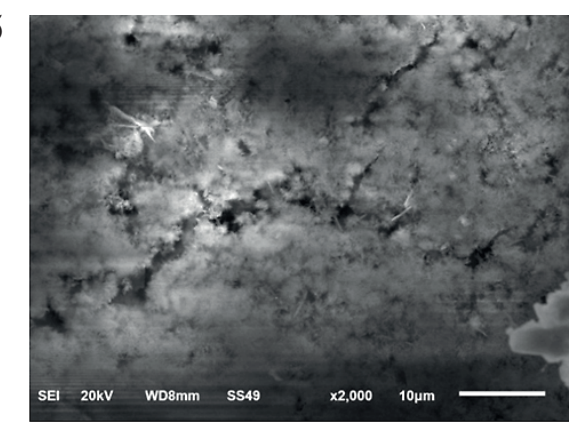

$\Gamma$

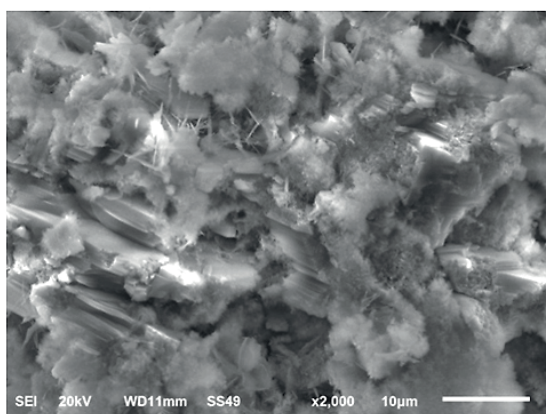


фид кальция, распределяясь в поровом пространстве, блокирует их поверхность, ограничивая контакт агрессивных ионов с продуктами твердения.

На микрофотографиях четко видно, что полисульфид кальция заполняет собой поровое пространство цементного камня при его твердении и не дает компонентам агрессивной среды проникать внутрь камня и разрушать его.

\section{ЗАКЛЮЧЕНИЕ:}

1. Применение полисульфида кальция в тампонажных растворах является эффективным способом повышения долговечности цементного камня при воздействии агрессивных флюидов, за счет кольматации пор и ингибирования их поверхности.
2. Полисульфид кальция не ухудшает реологические свойства тампонажных растворов и их прокачиваемость, позволяя нормально обеспечить процессы цементирования обсадных колонн.

3. Добавка полисульфида кальция в цементные растворы повышает прочность и снижает проницаемость получаемого цементного камня.

4. Наиболее эффективной является технология ввода полисульфида кальция в сухой тампонажный материал с его последующей дезинтеграторной обработкой.

5. Выявленные особенности изменения свойств раствора и камня на портландцементной основе показали перспективу применения нанодобавок полисульфида кальция для получения долговечных заливных бетонных конструкций.

\section{REFERENCES}

1. Agzamov F.A., Izmuhambetov B.S., Tokunova E.F. Himija tamponazhnyh i promyvochnyh rastvorov [Chemistry of grouting and flushing solutions]. Saint-Petersburg, Nedra, 2011. 268 p. (In Russian).

2. Shmelev P.S. Burenie glubokih skvazhin v uslovijah anomal'nogo vozdejstvija korrozionnoaktivnyh sred [Drilling of deep wells in the conditions of the abnormal influence of corrozive environments]. Moscow, Nauka, 1998. 351 p. (In Russian).

3. Moskvin V.M., Ivanov F.M., Alekseev S.N., Guzeev E.A. Korrozija betona i zhelezobetona, metody ih zashhity [Corrosion of concrete and reinforced concrete, methods of their protection]. Moscow, Strojizdat, 1980. 536 p. (In Russian).

4. Kind V.V. Korrozija cementov i betona v gidrotehnicheskih sooruzhenijah [Corrosion of cements and concrete in hydraulic engineering constructions]. Moscow, Gosjenergoizdat, 1955. 230 p. (In Russian).

5. Mamadzhanov U.D. Korrozija tamponazhnyh cementov v uglekislotnoj srede [Corrosion of grouting cements in the carbon dioxide environment]. Trudy AN UzSSR, otd. tehn. Nauk [Works of academy of Sciences of UZSSR, office of technical science]. 1976. pp. 69-73. (In Russian).

6. Rahimbaev Sh.M., Karpacheva E.N., Tolypina N.M. O vybore tipa cementa na osnove teorii kol'matacii pri slozhnom sostave agressivnoj sredy [About the choice of type of cement on the basis of the theory of a colmatation at the complex structure of a severe atmosphere]. Beton i zhelezobeton [Concrete and reinforced concrete]. 2012. no. 5. pp. 25-26. (In Russian).

7. Rahimbaev Sh.M., Tolypina N.M. Obosnovanie vybora tipa vjazhushhego dlja agressivnyh sred organicheskogo proishozhdenija na osnove teorii geterogennyh fiziko-himicheskih processov [Justification of the choice of type of the organic origin knitting for severe atmospheres on the basis of the theory of heterogeneous physical and chemical processes]. Vestnik Belgorodskogo gosudarstvennogo tehnologicheskogo universiteta im. V.G.Shuhova [Bulletin of the Belgorod state technological university of V.G. Shukhov]. 2016. no. 9. pp. 159-163. (In Russian).

8. Rahimbaev, Sh.M., Tolypina N.M. Povyshenie korrozionnoj stojkosti betonov putem racional'nogo vybora vjazhushhego i zapolnitelej [Increase in rust resistance of concrete by the rational choice knitting and fillers]. - Belgorod: Izd-vo BGTU, 2015. 321 p. (In Russian).

9. Volgushev.A.N., Paturoev V.V., Putljaev I.E. Krasil'nikova O.M. Primenenie sery dlja propitki porovoj struktury stroitel'nyh materialov [Use of sulfur for impregnation of steam structure of structural materials]. Beton i zhelezobeton [Concrete and reinforced concrete]. 1976. no. II. pp. 38-39. (In Russian).

10. Ignatiev A.V. Povyshenie prochnosti i vodonepronicaemosti rastvorov i betonov propitkoj ih zhidkim steklom [Increase in durability and water tightness of solutions and concrete impregnation by their liquid silica glass]. V kn.: Zhidkoe steklo: Materialy koordinacionnogo soveshhanija po proizvodstvu i prime-neniju zhidkogo stekla v stroitel'stve [In the book.: Liquid silica glass: Materials of a coordination meeting on production and use of liquid glass in construction]. Kiev. 1963. pp. 283-296. (In Russian).

11. Marchukajtis G.V. Vlijanie propitki betona monomerami na ego deformativnye svojstva [Concrete impregnation influence by monomers on its stress-strain properties]. Beton i zhelezobeton [Concrete and reinforced concrete]. 1977. no. 6. pp. 30-31. (In Russian).

12. Ovchinnikov V.P. Tehnologija burenija neftjanyh i gazovyh skvazhin: uchebnik dlja studentov vuzov [Technology of drilling of oil and gas wells]. Tyumen, 2014. 418 p. (In Russian).

13. Kravcov V.M., Kuznecov Ju.S., Mavljutov M.R., Agzamov F.A. Kreplenie vysokotemperaturnyh skvazhin v korrozionnoaktivnyh sredah [Cementing of high-temperature wells in the corrosive environments]. Moscow, Nedra, 1987. 190 p. (In Russian). 
14. Agzamov F.A., Izmuhambetov B.S. Dolgovechnost' tamponazhnogo kamnja v korrozionno-aktivnyh sredah [Durability of a grouting stone in the corrosive environments]. Saint-Petersburg, Nedra, 2005. 318 p. (In Russian).

15. Polak A.F. Matematicheskoe modelirovanie processa korrozii betona $\mathrm{v}$ zhidkih sredah [Mathematical model operation of process of corrosion of concrete in liquid environments]. Beton i zhelezobeton [Concrete and reinforced concrete]. 1988. no. 3. pp. 30-34. (In Russian).

16. Danjushevskij V.S., Tarnavskij A.P. Gazovaja serovodorodnaja korrozija tamponazhnyh cementov [Gas hydrosulphuric corrosion of grouting cements]. Gazovaja promyshlennost' [Gas industry]. 1977. no. 6. pp. 46-48. (In Russian).

17. Rahimbaev Sh.M., Avershina N.M. Modelirovanie processov himicheskoj korrozii stroitel'nyh materialov [Model operation of processes of chemical corrosion of structural materials]. Sbornik dokladov mezhdunarodnoj konferencii «Novye tehnologicheskie reshenija i jekonomicheskie problemy v proizvodstve betonov, drugih stroitel'nyh materialov i izdelij» [Reports of the international conference «New Technology Solutions and Economic Problems in Production of Concrete, Other Structural Materials and Products»]. Belgorod, 1996. pp. 167-172. (In Russian).

18. Kuncevich O.V., Mahinin B.V., Shangina N.N. Struktura cementnogo kamnja s dobavkami superplastifikatora i mikrokremnezema [Structure of a cement stone with additives of supersoftener and microsilicon dioxide]. Tsement [Cement]. 1992. no. 6. pp. 30-36. (In Russian).

19. Urkhanova L.A., Lkhasaranov S.A., RozinaV.Ye., Buyantuev S.L., Bardakhanov S.P. Increased corrosion resistance of basalt reinforced cement compositions with nanosilica. Nanotehnologii v stroitel'stve $=$ Nanotechnologies in Construction. 2014, Vol. 6, no. 4, pp. 15-29. Available at: http://nanobuild.ru/en_EN/ (Accessed 16.01.2019). (In Russian).

20. Massalimov I.A., Yanakhmetov M.R., Chuykin A.E. Strength and durability of Concrete modified by sulfur-based impregnating compounds. Nanotehnologii v stroitel'stve = Nanotechnologies in Construction. 2015, Vol. 7, no. 3, pp. 61-75. DOI: dx.doi.org/10.15828/2075-8545-2015-7-3-61-75. (In Russian).

21. Yanakhmetov M.R., Chuykin A.E., Massalimov I.A. Pore structure modification of cement concretes by impregnation with sulfur-containing compounds. Nanotehnologii v stroitel'stve = Nanotechnologies in Construction. 2015, Vol. 7, no. 1, pp. 63-72. DOI: dx.doi.org/10.15828/2075-8545-2015-7-1-63-72.

22. Agzamov F.A., Konesev G.V., Hafizov A.R. Application of disintigratory technology for the modification of materials used in the construction of wells. Part II. Nanotehnologii v stroitel'stve = Nanotechnologies in Construction. 2017, Vol. 9, no. 3, pp. 96-108. DOI: dx.doi.org/10.15828/2075-8545-2017-9-3-96-108. (In Russian).

\section{СПИСОК ЛИТЕРАТУРЫ}

1. Агзамов Ф.А., Измухамбетов Б.С., Токунова Э.Ф. Химия тампонажных и промывочных растворов. - СанктПетербург: ООО «Недра», 2011. - 268 с.

2. Шмелев П.С. Бурение глубоких скважин в условиях аномального воздействия коррозионноактивных сред. - Москва: Наука, 1998. - 351 с.

3. Москвин В.М., Иванов Ф.М., Алексеев С.Н., Гузеев Е.А. Коррозия бетона и железобетона, методы их защиты. Москва: Стройиздат, 1980. - 536 с.

4. Кинд В.В. Коррозия цементов и бетона в гидротехнических сооружениях. -Москва: Госэнергоиздат, $1955 .-230$ с.

5. Мамаджанов У.Д. Коррозия тампонажных цементов в углекислотной среде // Труды АН УзССР, отд. техн. наук. 1976. - С. 69-73.

6. Рахимбаев Ш.М., Карпачева Е.Н., Толыпина Н.М. О выборе типа цемента на основе теории кольматации при сложном составе агрессивной среды // Бетон и железобетон. - 2012. - № 5. - С. 25-26.

7. Рахимбаев Ш.М., Толыпина Н.М. Обоснование выбора типа вяжущего для агрессивных сред органического происхождения на основе теории гетерогенных физико-химических процессов // Вестник Белгородского государственного технологического университета им. В.Г. Шухова. - 2016. - № 9. - С. 159-163.

8. Рахимбаев Ш.М., Толыпина Н.М. Повышение коррозионной стойкости бетонов путем рационального выбора вяжущего и заполнителей. - Белгород: Изд-во БГТУ, 2015. - 321 с.

9. Волгушев А.Н., Патуроев В.В., Путляев И.Е., Красильникова О.М. Применение серы для пропитки поровой структуры строительных материалов // Бетон и железобетон. - 1976. - № II. - С. 38-39.

10. Игнатьев А.В. Повышение прочности и водонепроницаемости растворов и бетонов пропиткой их жидким стеклом // Жидкое стекло: Материалы координационного совещания по производству и применению жидкого стекла в строительстве. - Киев. - 1963. - С. 283-296.

11. Марчукайтис Г.В. Влияние пропитки бетона мономерами на его деформативные свойства // Бетон и железобетон. - 1977. - № 6. - С. 30-31.

12. Овчинников В.П. Технология бурения нефтяных и газовых скважин: учебник для студентов вузов. - Тюмень. 2014. $-418 \mathrm{c}$.

13. Кравцов В.М., Кузнецов Ю.С., Мавлютов М.Р., Агзамов Ф.А. Крепление высокотемпературных скважин в корразионно-активных средах. - Москва: Недра, 1987. - 190 с.

14. Агзамов Ф.А., Измухамбетов Б.С. Долговечность тампонажного камня в коррозионно-активных средах. - С-Пб.: Недра, 2005. - 318 c. 
15. Полак А.Ф. Математическое моделирование процесса коррозии бетона в жидких средах // Бетон и железобетон. -1988.- № 3. - С. 30-34.

16. Данюшевский В.С., Тарнавский А.П. Газовая сероводородная коррозия тампонажных цементов // Газовая промышленность. - 1977. - № 6. - С. 46-48.

17. Рахимбаев Ш.М., Авершина Н.М. Моделирование процессов химической коррозии строительных материалов // Сборник докладов международной конференции «Новые технологические решения и экономические проблемы в производстве бетонов, других строительных материалов и изделий». - Белгород, 1996. - С. 167-172.

18. Кунцевич О.В., Махинин Б.В., Шангина Н.Н. Структура цементного камня с добавками суперпластификатора и микрокремнезема // Цемент. - 1992. - № 6. - С. 30-36.

19. Урханова Л.А., Лхасаранов С.А., Розина В.Е., Буянтуев С.Л., Бардаханов С.П. Повышение коррозионной стойкости базальтофиброцементных композиций с нанокремнеземом // Нанотехнологии в строительстве. - 2014. - Том 6, № 4. - C. 15-29. - URL: http://nanobuild.ru/ru_RU/ (дата обращения: 16.01.2019).

20. Массалимов И.А., Янахметов М.Р., Чуйкин А.Е. Прочность и долговечность бетона, модифицированного пропиточными составами на основе серы // Нанотехнологии в строительстве. - 2015. - Том 7, № 3. - C. 61-75. - DOI: dx.doi.org/10.15828/2075-8545-2015-7-3-61-75.

21. Янахметов М.Р., Чуйкин А.Е., Массалимов И.А. Модифицирование поровой структуры цементных бетонов пропиткой серосодержащими растворами // Нанотехнологии в строительстве. - 2015. - Том 7, № 1. - C. 63-72. - DOI: dx.doi.org/10.15828/2075-8545-2015-7-1-63-72.

22. Агзамов Ф.А., Конесев Г.В., Хафизов А.Р. Применение дезинтеграторной технологии для модификации материалов, используемых при строительстве скважин. Часть II // Нанотехнологии в строительстве. - 2017. - Том 9, № 3. C. 96-108. - DOI: dx.doi.org/10.15828/2075-8545-2017-9-3-96-108.

\section{INFORMATION ABOUT THE AUTHORS}

Farit A. Agzamov, Doctor of science, Professor of the Department «Oil and Gas Well Drilling», Ufa State Petroleum Technological University; Kosmonavtov st. 1, Ufa, Russia, 450062, faritag@yandex.ru;

Elvira F. Tokunova, PhD of Chemistry, Associate Professor of the Depart-ment «Oil and Gas Well Drilling», Ufa State Petroleum Technological University; Kosmonavtov st. 1, Ufa, Russia, 450062, etokunova@yandex.ru;

Rival R. Sabirzianov, Graduate student of the Department «Oil and Gas Well Drilling», Ufa State Petroleum Technological University; Kosmonavtov st. 1, Ufa, Russia, 450062, rivalsaab@gmail.com

\section{ИНФОРМАЦИЯ ОБ АВТОРАХ}

Агзамов Фарит Акрамович, д.т.Н., проф., профессор кафедры «Бурение нефтяных и газовых скважин» ФГБОУ ВО «УГНТУ»; ул. Космонавтов 1, г. Уфа, Россия, 450062, faritag@yandex.ru

Токунова Эльвира Фаритовна, к.Х.н., доцент кафедры «Бурение нефтяных и газовых скважин» ФГБОУ ВО «УГНТУ»; ул. Космонавтов 1, г. Уфа, Россия, 450062, etokunova@yandex.ru

Сабирзянов Риваль Рамилевич, магистрант кафедры «Бурение нефтяных и газовых скважин» ФГБОУ ВО «УГНТУ»; ул. Космонавтов 1, г. Уфа, Россия, 450062, rivalsaab@gmail.com 